\title{
Screening of lettuce accessions for resistance to Fusarium oxysporum f. sp. lactucae race 1
}

\author{
Cléia Santos Cabral ${ }^{1}$ \& Ailton Reis ${ }^{2}$
}

${ }^{1}$ Departamento de Agronomia, Área de Fitossanidade, Universidade Federal Rural de Pernambuco, Av. Dom Manoel de Medeiros s/n, 52171-900, Recife, PE, Brazil; ${ }^{2}$ Embrapa Hortaliças, Cx. Postal 218, 70359-970, Brasília, DF, Brazil

Author for correspondence: Ailton Reis, e-mail: ailton.reis@embrapa.br

\begin{abstract}
Fusarium wilt caused by Fusarium oxysporum f. sp. lactucae (FOLAC) is one of the most important problems for lettuce growers because it causes major losses in production. To identify cultivars with potential for use in the management of the disease, 102 accessions were evaluated for resistance to isolates of race 1 of FOLAC. Initially, preliminary screening was done, using the isolate Fus173. Then, 47 materials selected as highly resistant and a susceptible control (Regina) were reevaluated for resistance to other isolates of FOLAC race 1 from different locations: Fus-202 and Fus-205, in October 2011, Fus-219 and Fus-222, in November 2011; and Fus-207, Fus-209, and Fus-220 in December 2011. Inoculation was performed on 25 day old seedlings in the greenhouse by the method of cutting the roots and immersing them in the conidial suspension. The evaluation was performed using a scale ranging from 0 (healthy plant) to 4 (dead plant). Resulting data was transformed into a disease index and submitted to an analysis of variance and means comparison by the Tukey test $(\mathrm{P}=0.05)$. Thirty-two accessions were identified with wide resistance spectrum to different isolates of the pathogen in the four periods of inoculation.
\end{abstract}

Key words: Lactuca sativa, Fusarium wilt, genetic resistance.

\section{INTRODUCTION}

Lettuce, Lactuca sativa L., is one of the most consumed vegetables in Brazil. In terms of economic importance it is the sixth most economically valuable vegetable crop in Brazil, and eighth in volume produced (Costa \& Sala, 2005). The most important lettuce variety group in terms of cultivated area and volume of production in Brazil is Crisp Leaf, which corresponds to approximately $60 \%$ of the national market. Then comes the crisphead segment, with $25 \%$ of the total market, followed by the smooth and other types (mimosa, romaine, colored cultivars, etc) responsible for $15 \%$ of the total (Costa \& Sala, 2005).

Diseases caused by soil-inhabiting fungi are very limiting for lettuce crops, often due to intensive use of fields for successive crops without crop rotation. These practices have caused a reduction in cultivated area and productivity (Lopes et al., 2010). Among the major fungal diseases of lettuce is Fusarium wilt, caused by the soil-borne fungus Fusarium oxysporum f. sp. lactucae Matuo and Motohashi. This disease was recently reported in Brazil, initially in the state of Espirito Santo (Ventura \& Costa, 2008), and then in other states of the Southern and Southeastern regions of Brazil (Cabral et al., 2009).

Isolates of $F$. oxysporum f. sp. lactucae are grouped into three races (1,2 and 3 ) according to their reaction on race-differential cultivars of lettuce (Fujinaga et al., 2003). In Japan, the presence of the three races has already been reported (Fujinaga et al., 2001, 2003; Yamauchi et al.,
2004). On the other hand, in other countries such as Italy, Portugal, Iran, USA and Brazil only race 1 has been reported (Pasquali et al., 2007; McCreight et al., 2005; Brunelli et al., 2010).

The management of Fusarium wilt of lettuce can be accomplished only by adopting a combination of control measures such as preventing infestation of new cultivation areas, using healthy or treated seeds and seedlings of good quality. The transit of equipment and people from infested fields to new areas should also be avoided. In areas already infested with the pathogen crop rotation should take place at least every three years, as well as soil solarization and the incorporation of manure (Matheron et al., 2005; Lopes et al., 2010; Matheron et al., 2010).

Despite all these measures recommended for the control of Fusarium wilt of lettuce, the most efficient and viable control method for the producer is the use of cultivars with genetic resistance. However, nothing is known about the level of resistance to Fusarium wilt in cultivars from different lettuce segments grown in Brazil. Moreover, there is a constant release of new cultivars by the breeding programs, and it is necessary to evaluate and characterize the new accessions in terms of resistance to root pathogens of economic importance for lettuce, particularly $F$. oxysporum f. sp. lactucae.

Thus, the objective of this study was to evaluate a set of lettuce cultivars and lines for resistance to Fusarium wilt, aiming to identify sources of resistance to race 1 of $F$. oxysporum f. sp. lactucae and analyze the resistance 
to different isolates of this pathogen race among the most promising accessions.

\section{MATERIALS AND METHODS}

\section{Pathogen isolates}

In this work eight $F$. oxysporum f. sp. lactucae isolates were used. They were characterized at formae specialis level on lettuce, other species from Asteraceae family and from other botanical families. They also were characterized as race 1 by inoculation on a set of differential cultivars of lettuce (Brunelli et al., 2010; Cabral et al., 2011) following the standard methodology (Fijinaga et al., 2001). Race identity of isolates was confirmed by PCR, using a set of specific primers (Cabral et al., 2011). After its characterization, isolates were deposited in the culture collection of plant pathogenic fungi "Professora Maria Menezes" - CMM as: CMM-3573 (Fus-173), CMM-3574 (Fus-202), CMM-3575 (Fus-205), CMM-3576 (Fus-207), CMM-3577 (Fus-209), CMM-3580 (Fus-219), CMM-3581 (Fus-220), and CMM-3583 (Fus-222).

\section{Preliminary screening of lettuce accessions for resistance to Fusarium oxysporum f. sp. lactucae race 1}

In this assay, the isolate Fus. 173 of $F$. oxysporum $\mathrm{f}$. sp. lactucae race 1 was used. This isolate was obtained from lettuce with wilt symptoms, collected in Antônio Carlos, Santa Catarina state. The fungus was grown in plates containing PDA for five days. After this period, three culture discs (5 $\mathrm{mm}$ diameter) were removed from actively growing cultures and placed in Erlenmeyer flasks containing $100 \mathrm{~mL}$ of potato-dextrose (PD). The flasks were placed on a shaker (140 RPM) for10 days at $25^{\circ} \mathrm{C}$ and 12-hour photoperiod. After this process, the culture was filtered through a double layer of cheesecloth and the concentration of spores in the resulting suspension was estimated using a haemocytometer. Subsequently, the spore suspension was adjusted to a concentration of $10^{6}$ microconidia $\mathrm{mL}^{-1}$.

The screening was carried out in May 2011 with 77 cultivars from various seed companies and 25 lines from the lettuce breeding program conducted by Embrapa Hortaliças. Two cultivars identified as highly susceptible in preliminary tests ('Regina' and 'Elisa'), were included as susceptible controls. Twenty five seeds of each accession were sown in polystyrene trays with 128 cells, filled with sterile substrate (Plantmax $\left.{ }^{\circledR}\right)$. The seedlings were inoculated 25-30 days after sowing, i.e., when they had four true leaves fully formed.

Inoculation was performed by removing the seedlings from the trays, washing the roots in water to remove the attached substrate, and cutting their ends (approximately $2 \mathrm{~cm}$ ) using sterile scissors. Subsequently, the roots were immersed for three minutes in a Becker flask containing 50 $\mathrm{mL}$ of the spore suspension. After that, the seedlings were transplanted to $3 \mathrm{~L}$ volume plastic pots containing a sterilized mixture of clay, manure, sand and carbonized sterilized rice straw. These pots were irrigated previously (one hour before planting). After this, $3 \mathrm{~mL}$ conidial suspension was added in the collar region of each seedling. The plants were not irrigated again on the day of inoculation to prevent loss of the inoculum through runoff. The experimental design was completely randomized with 104 treatments and three replications, represented by three pots containing four plants each. Plants were maintained in a greenhouse with air temperature varying from 23 to $35^{\circ} \mathrm{C}$ and a photoperiod of 12 hours.

Evaluation was carried out 30 days after inoculation and consisted in the observation of the presence of external (yellowing, necrosis and wilting) and internal (vascular browning) symptoms, which were confirmed by cutting the stem in a vertical direction using a scalpel. To quantify the severity of the disease we adopted a grade scale, ranging from 0 to 4 where: $0=$ plants with no symptoms, $1=$ plants with no symptoms of wilting or yellowing leaves, but with vascular browning; 2 = plants with intense vascular browning and early leaf wilting or yellowing, 3 = severely wilted plants, associated with leaf yellowing and necrosis, $4=$ dead plants (adapted from Santos, 1996).

From the grade values the disease indices (DI) were calculated by the formula of McKinney (McKinney et al., 1923): DI $(\%)=100 . \Sigma[(\mathrm{fv}) /(\mathrm{nx})]$, such that $\mathrm{f}=$ number of plants with the same grade; $\mathrm{v}=$ grade observed, $\mathrm{n}=$ total number of plants evaluated, and $\mathrm{x}=$ highest score on the scale. These rates were grouped into classes of reaction to the disease, using the resulting average for each accession: $0.00 \%=$ resembling the immune response, (IR); 0.01 to $25.00 \%=$ highly resistant (HR); 25.01 to $50.00 \%=$ moderately resistant (MR); 50.01 to $75.00 \%=$ moderately susceptible (MS); 75.01 to $100.00 \%=$ highly susceptible (HS); as adapted from Reis et al. (2004). The accessions that showed a response type similar to immune or highly resistant were selected to be evaluated for resistance to seven other isolates of $F$. oxysporum $\mathrm{f}$. sp. lactucae race 1 .

\section{Breadth of resistance to isolates of Fusarium oxysporum f. sp. lactucae race 1 of different geographic origins}

The lettuce accessions selected in the first trial were evaluated for resistance to seven additional isolates of the pathogen in three assays. In these assays the concentration of the inoculum was increased to $2 \times 10^{6}$ microconidia $\mathrm{mL}^{-1}$. The first breadth of resistance assay was carried out in October 2011. In this assay, 47 accessions considered HR, plus the cultivar 'Regina', considered HS, and used as control, were tested for resistance to isolates Fus-202 and Fus-205, collected in Muriaé-MG and Santa Cruz do Rio Pardo-SP, respectively. Seedling production, inoculum preparation and inoculation followed the previously described methodology here and as well as for other tests described below. The experimental design was completely randomized in a factorial arrangement of 48 (accessions) x two (isolates) with three replications. Each 
replication consisted of a pot with four plants. After inoculation plants were maintained in greenhouse with air temperature varying from 26 to $39^{\circ} \mathrm{C}$ and a photoperiod of 14 hours. The evaluation was performed 30 days after inoculation and the severity data were also used for calculating the DIs. The DI data were subjected to an analysis of variance and the means were compared by the Tukey test $(\mathrm{P}=0.05)$ through the SAS program.

The second breadth assay was carried out in November 2011. In this assay the same accessions and methodology were used as in breadth assay 1, but isolates Fus-219 and Fus-222 were used, from Colombo-PR and Itajaí-SC, respectively. After inoculation plants were maintained in greenhouse with air temperature varying from 25 to $40^{\circ} \mathrm{C}$ and a photoperiod of 14 hours.

The third breadth assay was carried out in December 2011. In this assay the same accessions and methodology were used as in assay 1, but with isolates Fus-207, Fus-209 and Fus-220 from Campinas-SP, Nova Friburgo-RJ, and Colombo-PR, respectively. After inoculation plants were maintained in greenhouse with air temperature varying from 23 to $38^{\circ} \mathrm{C}$ and photoperiod of 14 hours.

\section{RESULTS AND DISCUSSION}

In the preliminary assay none of the accessions included (cultivars or breeding lines) of lettuce showed an immune-type reaction (zero disease), to isolate Fus-173. Of 104 accessions tested, 30 (including the susceptible controls) reacted as susceptible (high or medium susceptibility). From this group, 19 accessions (18.6\%) were rated as highly susceptible, with DI ranging from $77.08 \%$ to $100 \%$, 25 accessions $(24.5 \%)$ were rated as moderately resistant with DI ranging from $27.08 \%$ to $47.91 \%$ and 47 accessions (46.1\%) were highly resistant with DI ranging from $2.08 \%$ to $25 \%$. These 47 accessions were preliminarily considered here as promising sources of resistance and potentially adequate for planting in areas where the disease is present. In the group of susceptible accessions, 19 cultivars belonged to segment "Butterhead". Likewise Garibaldi et al. (2004) evaluating 32 cultivars of lettuce of different segments found that seven cultivars (including some romaine and mimosa type) were resistant to Fusarium wilt, while the butterhead lettuce cultivars were all susceptible. These results indicate that butterhead cultivars should not be used in areas where Fusarium wilt occurs. Data obtained in this assay also indicated that in general cultivars from the mimosa segment: Mimosa, Green Salad Bowl, Oak Leaf Saladin, Red Salad Bowl, Salad Bowl Roxo, Read Salad Bowl Ultra Rosso, Red Mimosa Vermelha and Roxane were highly resistant to $F$. oxysporum f. sp. lactucae. This is in agreement with Scott et al. (2010) who found that two mimosa cultivars (Lolla Rossa and Red Rossa) were highly resistant to Fusarium wilt race 1 . These results indicate a low variability within the mimosa lettuce segment and suggest that they may all have a common origin. Therefore resistance to race 1 in this lettuce segment was effective for isolates from USA and from Brazil.

Thirty-two accessions featuring a wide spectrum of resistance to different isolates of the pathogen were identified along the four periods of inoculation. In the first breadth assay of resistance for isolate Fus-202, 38 out of the 47 accessions selected in the first test were highly resistant. However, seven accessions were only intermediately resistant and two were moderately susceptible. As for isolate Fus-205, one accession (Grand) showed an immunetype reaction, 41 accessions were highly resistant, three were intermediately resistant and two were moderately susceptible (Table 1). In this assay, considering the two isolates used, it was observed that the resistance classes, established to differentiate the accessions of lettuce in the preliminary screening, did not fit perfectly with the separation of accessions made by Tukey test at $5 \%$ (Table 1). In this case, the highly resistant accessions did not differ statistically from the intermediately resistant and moderately susceptible. It was also observed that there was no consistency in the results of nine accessions in relation to their resistance to two isolates of $F$. oxysporum $\mathrm{f}$. sp. lactucae. The accessions Amélia, Crespa Repolhuda, Red Star, and CNPH-54 were considered moderately resistant to isolate Fus-202 and highly resistant to Fus-205, while the cultivars Scarlet and Kaiser were moderately susceptible to Fus-202 and highly resistant to Fus-205. The cultivar Mônica was moderately resistant to Fus-202 and moderately susceptible to Fus-205. The cultivar Lavínia was highly resistant to Fus-202 and moderately susceptible to Fus-205, while Green Salad Bowl was highly resistant to Fus-202 and moderately resistant to Fus-205. The accessions Mimosa, Simpson, Red Salad Bowl Ultra Rosso, Mimosa Vermelha, AC-5009, Sabrina, Angelina, Vanda, AMX1-140, Hanson, Cinderela, Vanessa, Cubana, Donna, Grand, Red Salad Bowl, Itapuã, Salad Bowl Roxo, Lavínia, Maravilha das Quatro Estações, Green Salad Bowl, Romana Paris, Romana New, AMX1-133, Raider Plus-pl.04, Irene, AMX1-99, Saia Veia, Lucy Brown, Sofia, AMX1-30, AMX1-96, Elba, Pira Roxo, AMX1-108, Roxane, Laurel-pl.01, and Roxa 01 were highly resistant to both isolates (Table1).

These differences in resistance to each isolate are probably because some cultivars and lines may have a quantitative resistance, which can be influenced by the environment. Moreover, the more concentrated inoculum must have influenced the different result of this assay in relation to the preliminary screening. A higher inoculum level allowed a better separation of accessions with different resistance levels in this assay. Scott et al. (2010) observed that cultivars considered susceptible were more affected than the cultivars with intermediate resistance, when they were challenged with a higher concentration of inoculum. However, when the inoculum concentration was low there were no apparent differences between susceptible and resistant plants. Therefore, in this work the highest concentration of inoculum allowed a better resolution for 
TABLE 1 - Resistance levels of preliminarily selected lettuce accessions to four isolates of Fusarium oxysporum f. sp. lactucae race 1

\begin{tabular}{|c|c|c|c|c|c|}
\hline \multirow[t]{2}{*}{ Accession } & \multirow{2}{*}{$\begin{array}{l}\text { Varietal } \\
\text { Segment }\end{array}$} & \multicolumn{2}{|c|}{ DI" October 2011} & \multicolumn{2}{|c|}{ DI November 2011} \\
\hline & & Fus-202 & Fus-205 & Fus-219 & Fus-222 \\
\hline Regina $^{* *}$ & Butterhead & $89.58 \mathrm{aA}$ & $89.58 \mathrm{aA}$ & $89.58 \mathrm{aA}$ & $89.58 \mathrm{aA}$ \\
\hline Scarlet & Crisp leaf & $66.66 \mathrm{abA}$ & $18.75 \mathrm{~d}-\mathrm{gA}$ & $4.16 \mathrm{bcA}$ & $18.75 \mathrm{bcA}$ \\
\hline Kaiser & Crisphead & $58.75 \mathrm{bcA}$ & $6.25 \mathrm{fgB}$ & $6.25 \mathrm{bcA}$ & $6.25 \mathrm{bcA}$ \\
\hline Isabela & Crisp leaf & $48.33 \mathrm{~b}-\mathrm{dA}$ & $45.83 \mathrm{~b}-\mathrm{eA}$ & $6.25 \mathrm{bcB}$ & $25.00 \mathrm{bA}$ \\
\hline Amélia & Crisphead & $37.91 \mathrm{c}-\mathrm{eA}$ & $4.167 \mathrm{fgB}$ & $2.08 \mathrm{cB}$ & $22.91 \mathrm{bcA}$ \\
\hline Crespa Repolhuda & Crisphead & $35.83 \mathrm{c}-\mathrm{eA}$ & $14.58 \mathrm{~d}-\mathrm{gB}$ & $12.50 \mathrm{bcA}$ & $8.33 \mathrm{bcA}$ \\
\hline Red Star & Crisp leaf & $27.50 \mathrm{deA}$ & $18.75 \mathrm{~d}-\mathrm{gA}$ & $6.25 \mathrm{bcB}$ & $22.91 \mathrm{bcA}$ \\
\hline Oak leaf Saladin & Mimosa & $27.08 \mathrm{de} A$ & $37.50 \mathrm{~b}-\mathrm{fA}$ & $6.25 \mathrm{bcB}$ & $25.00 \mathrm{bA}$ \\
\hline CNPH-54 & Crisphead & $27.08 \mathrm{de} A$ & $25.00 \mathrm{c}-\mathrm{gA}$ & $18.75 \mathrm{bcA}$ & $18.75 \mathrm{bcA}$ \\
\hline Mônica & Crisp leaf & $27.08 \mathrm{deA}$ & $54.16 \mathrm{bcA}$ & $20.83 \mathrm{bcA}$ & $22.91 \mathrm{bcA}$ \\
\hline Mimosa & Mimosa & $25.00 \mathrm{de} A$ & $25.00 \mathrm{c}-\mathrm{gA}$ & $18.75 \mathrm{bcA}$ & $25.00 \mathrm{bA}$ \\
\hline Simpson & Crisp leaf & $25.00 \mathrm{de} A$ & $25.00 \mathrm{c}-\mathrm{gA}$ & $16.66 \mathrm{bcA}$ & $20.83 \mathrm{bcA}$ \\
\hline Red Salad Bowl U. Rosso & Mimosa & $25.00 \mathrm{de} A$ & $25.00 \mathrm{c}-\mathrm{gA}$ & $14.58 \mathrm{bcA}$ & $6.25 \mathrm{bcA}$ \\
\hline Mimosa vermelha & Mimosa & $25.00 \mathrm{de} A$ & $25.00 \mathrm{c}-\mathrm{gA}$ & $4.16 \mathrm{bcA}$ & $16.66 \mathrm{bcA}$ \\
\hline AC-5009 & Crisphead & $25.00 \mathrm{de} A$ & $4.17 \mathrm{f}-\mathrm{gB}$ & $4.16 \mathrm{bcA}$ & $6.25 \mathrm{bcA}$ \\
\hline Sabrina & Crisp leaf & $25.00 \mathrm{de} A$ & $25.00 \mathrm{c}-\mathrm{gA}$ & $16.66 \mathrm{bcA}$ & $25.00 \mathrm{bA}$ \\
\hline Angelina & Crisphead & $25.00 \mathrm{de} A$ & $25.00 \mathrm{c}-\mathrm{gA}$ & $6.25 \mathrm{bcB}$ & $25.00 \mathrm{bA}$ \\
\hline Vanda & Crisp leaf & $25.00 \mathrm{de} A$ & $20.83 \mathrm{c}-\mathrm{gA}$ & $12.50 \mathrm{bcB}$ & $25.00 \mathrm{bA}$ \\
\hline AMX1-140 & Crisp leaf & $25.00 \mathrm{de} A$ & $18.75 \mathrm{~d}-\mathrm{gA}$ & $6.25 \mathrm{bcB}$ & $25.00 \mathrm{bA}$ \\
\hline Hanson & Crisphead & $25.00 \mathrm{de} A$ & $8.33 \mathrm{f}-\mathrm{gB}$ & $4.16 \mathrm{bcA}$ & $4.16 \mathrm{cA}$ \\
\hline Cinderela & Crisp leaf & $25.00 \mathrm{de} A$ & $25.00 \mathrm{c}-\mathrm{gA}$ & $14.58 \mathrm{bcA}$ & $25.00 \mathrm{bA}$ \\
\hline Vanessa & Crisp leaf & $25.00 \mathrm{de} A$ & $14.58 \mathrm{~d}-\mathrm{gA}$ & $6.25 \mathrm{bcA}$ & $14.58 \mathrm{bcA}$ \\
\hline Cubana & Crisp leaf & $25.00 \mathrm{de} A$ & $25.00 \mathrm{c}-\mathrm{gA}$ & $18.75 \mathrm{bcA}$ & $22.91 \mathrm{bcA}$ \\
\hline Donna & Romaine & $25.00 \mathrm{de} A$ & $22.91 \mathrm{c}-\mathrm{gA}$ & $12.50 \mathrm{bcA}$ & $20.83 \mathrm{bcA}$ \\
\hline Grand & Crisp leaf & $25.00 \mathrm{de} A$ & $0.00 \mathrm{gB}$ & $6.25 \mathrm{bcA}$ & $10.41 \mathrm{bcA}$ \\
\hline Red Salad Bowl & Mimosa & $25.00 \mathrm{de} A$ & $14.58 \mathrm{~d}-\mathrm{gA}$ & $12.50 \mathrm{bcA}$ & $14.58 \mathrm{bcB}$ \\
\hline Itapuã & Crisp leaf & $25.00 \mathrm{de} A$ & $20.83 \mathrm{c}-\mathrm{gA}$ & $18.75 \mathrm{bcA}$ & $25.00 \mathrm{bA}$ \\
\hline Salad Bowl Roxo & Mimosa & $25.00 \mathrm{de} A$ & $10.41 \mathrm{f}-\mathrm{gA}$ & $8.33 \mathrm{bcB}$ & $25.00 \mathrm{bA}$ \\
\hline Lavínia & Mimosa & $25.00 \mathrm{de} A$ & $70.83 \mathrm{abA}$ & $20.83 \mathrm{bcA}$ & $25.00 \mathrm{bA}$ \\
\hline Maravilha das 4 estações & Butterhead & $25.00 \mathrm{de} A$ & $25.00 \mathrm{c}-\mathrm{gA}$ & $14.58 \mathrm{bcB}$ & $25.00 \mathrm{bA}$ \\
\hline Green Salad Bowl & Mimosa & $25.00 \mathrm{deB}$ & $47.91 \mathrm{~b}-\mathrm{dA}$ & $6.25 \mathrm{bcB}$ & $25.00 \mathrm{bA}$ \\
\hline Romana Paris & Romaine & $25.00 \mathrm{deA}$ & $22.91 \mathrm{c}-\mathrm{gA}$ & $2.08 \quad \mathrm{cA}$ & $8.33 \mathrm{bcA}$ \\
\hline Romana New & Romaine & $25.00 \mathrm{de} A$ & $25.00 \mathrm{c}-\mathrm{gA}$ & $12.50 \mathrm{bcB}$ & $25.00 \mathrm{bA}$ \\
\hline AMX1-133 & Crisp leaf & $25.00 \mathrm{de} A$ & $25.00 \mathrm{c}-\mathrm{gA}$ & $2.08 \mathrm{cB}$ & $25.00 \mathrm{bA}$ \\
\hline Raider Plus pl.04 & Crisphead & $12.50 \mathrm{eA}$ & $12.50 \mathrm{e}-\mathrm{gA}$ & $12.50 \mathrm{bcA}$ & $12.50 \mathrm{bcA}$ \\
\hline Irene & Crisphead & $25.00 \mathrm{de} A$ & $20.83 \mathrm{c}-\mathrm{gA}$ & $6.66 \mathrm{bcA}$ & $6.66 \mathrm{bcA}$ \\
\hline AMX1-99 & Crisp leaf & $25.00 \mathrm{de} A$ & $18.75 \mathrm{~d}-\mathrm{gA}$ & $4.16 \mathrm{bcB}$ & $25.00 \mathrm{bA}$ \\
\hline Saia Veia & Butterhead & $25.00 \mathrm{de} A$ & $20.83 \mathrm{c}-\mathrm{gA}$ & $10.41 \mathrm{bcA}$ & $20.83 \mathrm{bcA}$ \\
\hline Lucy Brown & Crisphead & $25.00 \mathrm{de} A$ & $22.91 \mathrm{c}-\mathrm{gA}$ & $25.00 \mathrm{bA}$ & $25.00 \mathrm{bA}$ \\
\hline Sofia & Romaine & $25.00 \mathrm{de} A$ & $25.00 \mathrm{c}-\mathrm{gA}$ & $16.66 \mathrm{bcB}$ & $25.00 \mathrm{bA}$ \\
\hline AMX1-30 & Crisp leaf & $22.91 \mathrm{deA}$ & $25.00 \mathrm{c}-\mathrm{gA}$ & $8.33 \mathrm{bcB}$ & $25.00 \mathrm{bA}$ \\
\hline AMX1-96 & Crisp leaf & $22.91 \mathrm{de} A$ & $22.91 \mathrm{c}-\mathrm{gA}$ & $8.33 \mathrm{bcB}$ & $25.00 \mathrm{bA}$ \\
\hline Elba & Crisp leaf & $22.91 \mathrm{eA}$ & $22.91 \mathrm{c}-\mathrm{gA}$ & $10.41 \mathrm{bcB}$ & $22.91 \mathrm{bcA}$ \\
\hline Pira Roxa & Crisp leaf & $20.83 \mathrm{eA}$ & $2.08 \mathrm{gB}$ & $16.66 \mathrm{bcA}$ & $6.25 \mathrm{bcA}$ \\
\hline AMX1-108 & Crisp leaf & $20.83 \mathrm{eA}$ & $20.83 \mathrm{c}-\mathrm{gA}$ & $12.50 \mathrm{bcA}$ & $20.83 \mathrm{bcA}$ \\
\hline Roxane & Mimosa & $18.75 \mathrm{eA}$ & $18.75 \mathrm{~d}-\mathrm{gA}$ & $6.25 \mathrm{bcA}$ & $14.58 \mathrm{bcA}$ \\
\hline Laurel pl.04 & Crisphead & $16.66 \mathrm{eA}$ & $16.66 \mathrm{~d}-\mathrm{gA}$ & $2.08 \mathrm{cA}$ & $16.66 \mathrm{bcA}$ \\
\hline Roxa 01 & Crisp leaf & $14.58 \mathrm{eA}$ & $10.41 \mathrm{fgA}$ & $10.41 \mathrm{bcA}$ & $6.25 \mathrm{bcA}$ \\
\hline
\end{tabular}

"DI (Disease index) values followed by the same uppercase letter within a row or lowercase letter within a column do not differ statistically according to the Tukey test $(\mathrm{P}=0.05)$.

${ }^{* *}$ Cultivar Regina included as highly susceptible control.

differentiation of degrees of susceptibility between some cultivars. Another factor that may explain the differences between the results of this assay as compared with the results of the preliminary selection would be the difference in aggressiveness among isolates; for example, isolate Fus202 was more aggressive than Fus-205 toward six accessions. 
Isolates belonging to the same race, coming from different geographical regions, can show differences in their ability to cause disease. These differences between isolates may also explain the disparities of the response of resistance observed in some accessions in this assay.

In the second breadth assay, all 47 accessions were classified as highly resistant to isolates Fus-219 and Fus-222. Accessions classified as highly resistant differed significantly (Table 1) from the susceptible control, according to Tukey test $(\mathrm{P}=0.05)$. Comparing the two Fusarium isolates, it was observed that isolate Fus-222 was more aggressive toward 16 accessions. Although this experiment had been carried out at another time of the year and with a higher inoculum concentration, it was observed that the tested accessions kept the same level of resistance presented in the preliminary screening. The results of this assay indicate that the differences in resistance, as presented by the accession in the preliminary selection and in the third assay, are more due to the differences in aggressiveness among isolates of the pathogen than to the inoculum concentration.

In the third assay 46 out of 47 accessions were classified as either highly resistant or moderately resistant to isolate Fus207. For isolate Fus-209, 46 accessions were classified as highly resistant and one accession as moderately resistant. In relation to isolate Fus-220, 41 accessions of lettuce were classified as highly resistant and six as moderately resistant. In this experiment plants classified as intermediately resistant and highly resistant differed significantly (Table 2) from the susceptible control, according to Tukey test $(\mathrm{P}=0.05)$. The phenotypic classes of resistance also did not show a good match to the grouping of accessions obtained using the Tukey test $(\mathrm{P}=0.05)$, because the plants classified as intermediately resistant did not differ significantly from those classified as highly resistant. In this third assay, it was also observed that there were no consistent results from seven accessions for the three pathogen isolates. The cultivar Maravilha das Quatro Estações was highly resistant to isolates Fus-209 and Fus220 and moderately resistant to Fus-207, while accessions AMX1-99, Lucy Brown, Crespa Repolhuda, Donna, and Amélia were highly resistant to isolates Fus-207 and Fus-209 and moderately resistant to Fus-220. The cultivar Red Star was considered highly resistant to Fus-207 and moderately resistant to Fus-209 and 220. Accessions AMX1-133, CNPH54, AMX1-30, Mimosa, Angelina, Green Salad Bowl, Red Salad Bowl, Isabela, Itapuã, Mimosa Vermelha, Lavínia, Sabrina, Sofia, Laurel-pl.04, Romana Paris, Elba, Cinderela, AMX1-106, Scarlet, Simpson, Oak leaf Saladin, AMX1-140, Mônica, Hanson, Salad Bowl Roxo, Saia Veia, Raider Pluspl.04, Vanda, Irene, Cubana, Vanessa, Red Salad Bowl Ultra Rosso, Kaiser, Romana New, Roxane, Pira Roxa, Grand, AC5009, AMX1-108, Amélia, and Roxa 01 were highly resistant to all three fungal strains (Table 2).

Among the consistently highly resistant cultivars in all experiments is the cultivar 'Pira Roxa', a bright red lettuce cultivar belonging to the crisp leaf segment. This cultivar was bred in Brazil, and is resistant to other major lettuce pathogens such as Thielaviopsis basicola, Bremia lactucae and lettuce mosaic virus, pathotype II. This is acknowledged as the first tropical red crisp leaf lettuce cultivar carrying multiple resistance to diseases in Brazil (Sala \& Costa, 2005; Sala et al., 2008). Now we have the evidence that this cultivar is also resistant to Fusarium wilt and hence a good choice for Brazilian producers of lettuce and a source of resistance to various diseases which can be used in lettuce breeding programs in Brazil and elsewhere. Another important result was the observation of resistance to Fusarium wilt found in cultivars such as Lucy Brown and Vanda. The cultivar Lucy Brown has been the most widely planted crisphead lettuce cultivar in Brazil for more than a decade, because of its high tolerance to summer conditions. This cultivar is also tolerant to bacterial spot (Xanthomonas campestris pv. vitians). However, its cultivation in areas with incidence of T. basicola and B. lactucae has been limited due to its susceptibility to these pathogens (Costa \& Sala, 2005). Another cultivar that was resistant in all tests and is of particular interest is Vanda. This is the most cultivated crisp leaf lettuce cultivar in Brazil, because it is very uniform, it has great commercial value due to its resistance to transport and handling and is resistant to LMV (Costa \& Sala, 2005).

Considering all the assays, conducted in different months of the year, it was observed that cultivars from the romaine segment showed good levels of resistance to Fusarium wilt. The cultivars Sofia, Romana New, and Romana Paris were highly resistant to all pathogen isolates, while Donna was intermediately resistant to Fus-220 and highly resistant to the other isolates. The results obtained here were similar to those reported by Matheron et al. (2005) in trials conducted in fields that were naturally infested with $F$. oxysporum f. sp. lactucae in Arizona. Those authors identified two lettuce cultivars of the romaine segment (Slugger and King Louie), out of 16 cultivars tested, showing low levels of disease, and therefore considered them to be resistant or tolerant to the pathogen. A similar result was obtained in California by Scott et al. (2010, 2012), who identified three resistant romaine cultivars (Caeser, Forest Green and King Henry) in field trials. As observed for cultivars of the mimosa segment, these results also indicate a low genetic variability within this lettuce segment and suggest that they all have a common origin.

As observed before, all cultivars of the romaine segment and most cultivars of mimosa segment showed excellent resistance levels in this study. However, this is not always the case, since Scott et al. $(2010,2012)$ demonstrated that some romaine and mimosa segment cultivars were severely attacked by the pathogen when tested under controlled greenhouse conditions. Therefore, there is not always a consistent association between phenotypic type and cultivar susceptibility. This was also observed in the case of butterhead lettuce. Although there are known limitations for cultivating butterhead lettuce in places where Fusarium wilt occurs, two cultivars from this segment behaved as resistant 
TABLE 2 - Resistance levels of preliminarily selected lettuce accessions to three isolates of Fusarium oxysporum f. sp. lactucae race 1 (trial performed in December 2011)

\begin{tabular}{|c|c|c|c|}
\hline Acession & DI* Fus-207 & DI Fus-209 & DI Fus-220 \\
\hline Regina $^{* *}$ & $87.5 \mathrm{aA}$ & $79.16 \mathrm{aA}$ & $81.25 \mathrm{aA}$ \\
\hline Maravilha das 4 estações & $29.16 \mathrm{bA}$ & $22.91 \mathrm{bA}$ & $25.00 \mathrm{c}-\mathrm{eA}$ \\
\hline AMX1-133 & $25.00 \mathrm{bA}$ & $25.00 \mathrm{bA}$ & $25.00 \mathrm{c}-\mathrm{eA}$ \\
\hline CNPH-54 & $25.00 \mathrm{bA}$ & $25.00 \mathrm{bA}$ & $25.00 \mathrm{c}-\mathrm{eA}$ \\
\hline AMX1-30 & $25.00 \mathrm{bA}$ & $18.75 \mathrm{bA}$ & $25.00 \mathrm{c}-\mathrm{eA}$ \\
\hline Mimosa & $25.00 \mathrm{bA}$ & $25.00 \mathrm{bA}$ & $25.00 \mathrm{c}-\mathrm{eA}$ \\
\hline AMX1-99 & $25.00 \mathrm{bA}$ & $25.00 \mathrm{bA}$ & $27.08 \mathrm{~b}-\mathrm{eA}$ \\
\hline Angelina & $25.00 \mathrm{bA}$ & $18.75 \mathrm{bA}$ & $25.00 \mathrm{c}-\mathrm{eA}$ \\
\hline Green Salad Bowl & $25.00 \mathrm{bA}$ & $25.00 \mathrm{bA}$ & $25.00 \mathrm{c}-\mathrm{eA}$ \\
\hline Red Salad Bowl & $25.00 \mathrm{bA}$ & $20.83 \mathrm{bA}$ & $22.91 \mathrm{c}-\mathrm{eA}$ \\
\hline Isabela & $25.00 \mathrm{bA}$ & $25.00 \mathrm{bA}$ & $25.00 \mathrm{c}-\mathrm{eA}$ \\
\hline Itapuã & $25.00 \mathrm{bA}$ & $25.00 \mathrm{bA}$ & $25.00 \mathrm{c}-\mathrm{eA}$ \\
\hline Mimosa Vermelha & $25.00 \mathrm{bA}$ & $18.75 \mathrm{bA}$ & $25.00 \mathrm{c}-\mathrm{eA}$ \\
\hline Lavínia & $25.00 \mathrm{bA}$ & $25.00 \mathrm{bA}$ & $25.00 \mathrm{c}-\mathrm{eA}$ \\
\hline Sabrina & $25.00 \mathrm{bA}$ & $25.00 \mathrm{bA}$ & $25.00 \mathrm{c}-\mathrm{eA}$ \\
\hline Sofia & $25.00 \mathrm{bA}$ & $22.91 \mathrm{bA}$ & $25.00 \mathrm{c}-\mathrm{eA}$ \\
\hline Laurel pl.04 & $25.00 \mathrm{bA}$ & $25.00 \mathrm{bA}$ & $25.00 \mathrm{c}-\mathrm{eA}$ \\
\hline Romana Paris & $25.00 \mathrm{bA}$ & $16.66 \mathrm{bA}$ & $25.00 \mathrm{c}-\mathrm{eA}$ \\
\hline Elba & $25.00 \mathrm{bA}$ & $25.00 \mathrm{bA}$ & $25.00 \mathrm{c}-\mathrm{eA}$ \\
\hline Red Star & $25.00 \mathrm{bA}$ & $29.16 \mathrm{bA}$ & $41.66 \mathrm{bA}$ \\
\hline Cinderela & $25.00 \mathrm{bA}$ & $18.75 \mathrm{bA}$ & $25.00 \mathrm{c}-\mathrm{eA}$ \\
\hline AMX1-96 & $25.00 \mathrm{bA}$ & $22.91 \mathrm{bA}$ & $25.00 \mathrm{c}-\mathrm{eA}$ \\
\hline Scarlet & $25.00 \mathrm{bA}$ & $12.50 \mathrm{bB}$ & $25.00 \mathrm{c}-\mathrm{eA}$ \\
\hline Simpson & $25.00 \mathrm{bA}$ & $20.83 \mathrm{bA}$ & $25.00 \mathrm{c}-\mathrm{eA}$ \\
\hline Oak leaf Saladin & $25.00 \mathrm{bA}$ & $25.00 \mathrm{bA}$ & $25.00 \mathrm{c}-\mathrm{eA}$ \\
\hline AMX1-140 & $22.91 \mathrm{bcA}$ & $25.00 \mathrm{bA}$ & $25.00 \mathrm{c}-\mathrm{eA}$ \\
\hline Mônica & $22.91 \mathrm{bcA}$ & $25.00 \mathrm{bA}$ & $25.00 \mathrm{c}-\mathrm{eA}$ \\
\hline Hanson & $22.91 \mathrm{bcA}$ & $25.00 \mathrm{bA}$ & $25.00 \mathrm{c}-\mathrm{eA}$ \\
\hline Salad Bowl Roxo & $22.91 \mathrm{bcA}$ & $25.00 \mathrm{bA}$ & $20.83 \mathrm{c}-\mathrm{eA}$ \\
\hline Saia veia & $22.91 \mathrm{bcA}$ & $20.83 \mathrm{bA}$ & $25.00 \mathrm{c}-\mathrm{eA}$ \\
\hline Crespa Repolhuda & $22.91 \mathrm{bcA}$ & $25.00 \mathrm{bA}$ & $27.08 \mathrm{~b}-\mathrm{eA}$ \\
\hline Raider Plus pl.04 & $22.91 \mathrm{bcA}$ & $18.75 \mathrm{bA}$ & $25.00 \mathrm{c}-\mathrm{eA}$ \\
\hline Vanda & $22.91 \mathrm{bcA}$ & $20.83 \mathrm{bA}$ & $22.91 \mathrm{c}-\mathrm{eA}$ \\
\hline Irene & $22.91 \mathrm{bcA}$ & $22.91 \mathrm{bA}$ & $25.00 \mathrm{c}-\mathrm{eA}$ \\
\hline Lucy Brown & $22.91 \mathrm{bcA}$ & $25.00 \mathrm{bA}$ & $33.33 \mathrm{bcA}$ \\
\hline Cubana & $22.91 \mathrm{bcA}$ & $25.00 \mathrm{bA}$ & $25.00 \mathrm{c}-\mathrm{eA}$ \\
\hline Donna & $22.91 \mathrm{bcA}$ & $25.00 \mathrm{bA}$ & $29.16 \mathrm{~b}-\mathrm{dA}$ \\
\hline Vanessa & $20.84 \mathrm{bcA}$ & $25.00 \mathrm{bA}$ & $12.50 \mathrm{eA}$ \\
\hline Red Salad Bowl U. Rosso & $20.83 \mathrm{bcAB}$ & $12.50 \mathrm{bB}$ & $25.00 \mathrm{c}-\mathrm{eA}$ \\
\hline Kaiser & $20.83 \mathrm{bcA}$ & $22.91 \mathrm{bA}$ & $25.00 \mathrm{c}-\mathrm{eA}$ \\
\hline Romana New & $20.83 \mathrm{bcA}$ & $25.00 \mathrm{bA}$ & $25.00 \mathrm{c}-\mathrm{eA}$ \\
\hline Roxane & $20.83 \mathrm{bcA}$ & $20.83 \mathrm{bA}$ & $25.00 \mathrm{c}-\mathrm{eA}$ \\
\hline Pira Roxa & $18.75 \mathrm{bcA}$ & $12.50 \mathrm{bA}$ & $25.00 \mathrm{c}-\mathrm{eA}$ \\
\hline Grand & $18.75 \mathrm{bcA}$ & $22.91 \mathrm{bA}$ & $25.00 \mathrm{c}-\mathrm{eA}$ \\
\hline AC-5009 & $18.75 \mathrm{bcA}$ & $22.91 \mathrm{bA}$ & $16.66 \mathrm{de} A$ \\
\hline AMX-108 & $14.58 \mathrm{bcA}$ & $25.00 \mathrm{bA}$ & $22.91 \mathrm{c}-\mathrm{eA}$ \\
\hline Amélia & $14.58 \mathrm{bcA}$ & $16.66 \mathrm{bA}$ & $35.41 \mathrm{bcA}$ \\
\hline Roxa 01 & $8.33 \mathrm{cB}$ & $25.00 \mathrm{bA}$ & $25.00 \mathrm{c}-\mathrm{eA}$ \\
\hline
\end{tabular}

*DI (Disease index) values followed by the same uppercase letter within a row or lowercase letter within a column do not differ statistically according to the Tukey test $(\mathrm{P}=0.05)$.

${ }^{* *}$ Cultivar Regina included as highly susceptible control.

in all tests. Saia Veia was highly resistant to all fungal isolates and Maravilha das Quatro Estações was also highly resistant to all isolates, except for Fus-207 for which it was moderately resistant.
Out of 47 inoculated accessions, 32 consistently showed broad resistance spectrum to different isolates of the pathogen in four inoculation seasons (Mimosa, Simpson, Red Salad Bowl Rosso, Mimosa Vermelha, AC- 
5009, Sabrina, Angelina, Vanda, AMX1-140, Hanson, Cinderela, Vanessa, Cubana, Grand, Red Salad Bowl Ultra Rosso, Itapuã, Salad Bowl Roxo, Romana Paris, Romana New, AMX1-133, Irene, Raider Plus-pl.04, Saia Veia, Sofia, AMX1-30, AMX1-96, Elba, Pira Roxa, AMX1-108, Roxane, Laurel pl.04 and Roxa 01). These cultivars and breeding lines of lettuce are promising sources of resistance to Fusarium wilt. These resistance sources can be used in future breeding programs and are probably adequate for planting in areas where the disease occurs.

The identification of resistance to Fusarium wilt in existing commercial cultivars of lettuce is another positive result of the present work as these are readily available for use by the lettuce growers without the need of a long breeding process. In addition, the cultivation of cultivars from different varietal segments with resistance to the pathogen, in a crop rotation, could be an alternative to promote the reduction of the inoculum, since this practice can minimize the incidence/severity of disease. Moreover, since most cultivars showed no immune-type resistance (no disease) it is still necessary to combine genetic resistance with other disease control measures. In addition, constant monitoring of the variability of the pathogen is needed, to prevent the emergence of new pathogen races.

\section{ACKNOWLEDGEMENT}

We thank Conselho Nacional de Desenvolvimento Científico e Tecnológico - CNPq for providing an MSc scholarship to C. Cabral and a research fellowship to A. Reis.

\section{REFERENCES}

Brunelli KR, Cabral CS, Gioria R, Kobori RF, Costa H, Reis A (2010) Presença da raça 1 de Fusarium oxysporum f. sp. lactucae em alface no Brasil. Tropical Plant Pathology 35:S222.

Cabral CS, Brunelli KR, Carvalho MRM, Santos Junior WN, Reis A (2009) Ocorrência de Fusarium oxysporum f. sp. lactucae em alface no Brasil. Tropical Plant Pathology 34:S174.

Cabral CS (2011) Caracterização de isolados de Fusarium oxysporum f. sp. lactucae das Regiões Sul e Sudeste do Brasil e identificação de acessos de alface resistentes. M.Sc. Dissertation, Universidade Federal Rural de Pernambuco. Recife PE, Brasil.

Costa CP, Sala FC (2005) A evolução da alfacicultura brasileira. Horticultura Brasileira 23:118-120.

Fujinaga M, Ogiso H, Tsuchiya N, Saito H (2001) Physiological specialization of Fusarium oxysporum f. sp. lactucae, a causal organism of fusarium root rot of crisp head lettuce in Japan. Journal of General Plant Pathology 67:205-206.
Fujinaga M, Ogosh H, Tuchiya N, Saito H, Yamanaka S, Nozue M, Kojima M (2003) Race 3, a new race of Fusarium oxysporum f. sp. lactucae determined by a differential system with commercial cultivars. Journal of General Plant Pathology 69:23-28.

Garibaldi A, Gilardi G, Gullino ML (2004) Varietal resistance of lettuce to Fusarium oxysporum f. sp. lactucae. Crop Protection 23:845-851.

Lopes CA, Quezado-Duval AM, Reis A (2010) Doenças da alface. Brasília DF, Brazil. Embrapa Hortaliças.

Matheron ME, McCreight JD, Tickes BR, Porchas M (2005) Effect of planting date, cultivar, and stage of plant development on incidence of Fusarium wilt of lettuce in desert production fields. Plant Disease 89:565-570.

Matheron ME, Porchas M (2010) Evaluation of soil solarization and flooding as management tools for fusarium wilt of lettuce. Plant Disease 94:1323-1328.

McCreight JD, Matheron ME, Tickes BR, Platts B (2005) Fusarium wilt race 1 on lettuce. HortScience 40:529-531.

McKinney HH (1923) Influence of soil temperature and moisture on infection of wheat seedlings by Helminthosporium sativum. Journal of Agricultural Research 26:195-218.

Pasquali M, Dematheis F, Gullino ML, Garibaldi A (2007) Identification of race 1 of Fusarium oxysporum f. sp. lactucae on lettuce by inter-retrotransposon sequence-characterized amplified region technique. Phytopathology 97:987-996.

Reis A, Giordano LB, Lopes CA, Boiteux LS (2004) Novel sources of multiple resistance to three races of Fusarium oxysporum f. sp. lycopersici in Lycopersicon germplasm. Crop Breeding and Applied Biotechnology 4:495-502.

Sala FC, Costa CP (2005) 'PIRA ROXA': cultivar de alface crespa de cor vermelha intensa. Horticultura Brasileira 23:158-159.

Sala FC, Costa CP, Teixeira LD, Fabri EG, Blat SF (2008) Reação de cultivares de alface a Thielaviopsis basicola. Horticultura Brasileira 26:398-400.

Santos JRM (1996) Methodology for screening tomato to Fusarium wilt, Verticillium wilt, gray leaf spot, early blight, and Septoria leaf spot. In: Proceedings of the International Symposium on Tropical Tomato Diseases. Recife PE, Brazil. pp. 164-166.

Scott JC, Kirkpatrick SC, Gordon TR (2010) Variation in susceptibility of lettuce cultivars to Fusarium wilt caused by Fusarium oxysporum f. sp. lactucae. Plant Pathology 59:139-146.

Scott JC, Gordon TR, Kirkpatrick SC, Koike ST, Matheron ME, Ochoa OE, Truco MJ, Michelmore M (2012) Crop rotation and genetic resistance reduce risk of damage from Fusarium wilt in lettuce. California Agriculture 66:20-24.

Ventura JA, Costa H (2008) Fusarium wilt caused by Fusarium oxysporum on lettuce in Espirito Santo, Brazil. Plant Disease 92:976.

Yamauchi N, Shimazu J, Horiuchi S, Satou M, Shirakawa T (2004) Physiological races and vegetative compatibility groups of butterhead lettuce isolates of Fusarium oxysporum f. sp. lactucae in Japan. Journal of General Plant Pathology 70:308-313. 